\title{
Akıllı Turizm Destinasyonları: Antalya Destinasyonunun Akılı Turizm Uygulamalarının İncelenmesi
}

\section{Smart Tourism Destinations: Review of Smart Tourism Applications of Antalya Destination}

\author{
Dr. Pınar ÇELIKK \\ Akdeniz Üniversitesi \\ Sosyal Bilimler MYO \\ E-posta: pnr.celik@gmail.com \\ Orcid Id: 0000-0003-0599-4086
}

\author{
Dr. Yunus TOPSAKAL \\ Adana Bilim ve Teknoloji Üniversitesi \\ Turizm Fakültesi \\ E-posta:Topsakal.yunus@gmail.com \\ Orcid Id: 0000-0003-3202-5539
}

\section{Öz}

Akıllı turizm uygulamalarında bulunan şehirler rekabetçiliğini arttırabildiği için turistlerin deneyimlerini de arttırmaktadır. Bu çalışmanın amacı Türkiye'de önemli bir turizm destinasyonu olan Antalya destinasyonunun uygulamalarını akıllı turizm destinasyonları kapsamında incelemektir. Bu amaçla çalışmada öncelikle araştırma konusu olan akıllı turizm destinasyonu ile ilgili kuramsal çerçeve incelenmiştir. Sonrasında Antalya'nın akıllı turizm uygulamalarına ilişkin veriler elde edebilmek için doküman inceleme ve gözlem yöntemlerini içeren durum çalışması (örnek olay) gerçekleştirilmiştir. Çalışma sonucunda Antalya destinasyonunun Türkiye'nin akıllı bir turizm destinasyonu olması ve turistler tarafından Antalya destinasyonunun akıllı turizm destinasyonu olarak tanınması için önerilerde bulunulmaktadır. Türkiye'nin önemli turizm destinasyonlarından birisi olan Antalya'nın akıllı turizm destinasyonu olma yolundaki çalışmaları incelendiğinde uygulamaların yeni başladığı ve Antalya'nın yolun çok başında olduğu söylenebilir.

Anahtar Kelimeler: Akıllı şehir, Akıllı turizm, Turizm, Antalya

\section{Abstract}

The cities which apply smart tourism applications are increasing the experience of tourists as they can increase their competitiveness. The purpose of this study is to examine the applications of the Antalya destination, which is an important tourism destination in Turkey, within the scope of smart tourism destinations. For this purpose, the theoretical framework of the smart tourism destination has been examined. Afterwards, a case study including document review and observation methods was carried out to obtain data on smart tourism applications of Antalya destination. Then, proposals are made for Antalya destination to be a smart tourism destination and to be recognized as a smart tourism destination by the tourists. As a result, in terms of Antalya destination which is one of the important tourism destinations of Turkey, it can be said that the applications have just started and Antalya destination is at the very beginning of the road.

Keywords: Smart City, Smart Tourism, Tourism, Antalya 


\section{Giriş}

Akıllı şehir kavramı, kentsel nüfusun hızlı artışı ile başa çıkmak için yetkililerin karşılaştıkları karmaşıklık ve yönetim zorluklarından dolayı ortaya çıkmaktadır. Harrison vd. (2010, 1) 'akıllı' sıfatını gerçek zamanlı ve gerçek dünya verilerini kullanma, bu verileri bütünleştirme, paylaşma ve daha iyi operasyonel kararlar vermek için analitik, modelleme ve görselleştirmeyi kullanma olarak tanımlamıştır. Bu sıfat kaynak optimizasyonu, etkin ve adil yönetişim, sürdürülebilirlik ve yaşam kalitesi elde etmek için yenilikçi teknolojileri kullanmaya yönelik çabaları tanımlamak için şehirlere (akıllı şehir) eklenmiştir (Gretzel vd., 2015, 179). Hızlı kentleşme, bölgesel kalkınma ve ekonomik teşviklerden dolayı 20. yüzyılın ilk yıllarında şehirlerin çoğunda nüfus artışı, trafik sorunları, doğal kaynakların aşırı tüketimi, çevre kirliliği gibi pek çok sorun başlamıştır (Kim ve Han, 2012: 151). Bu sorunları azaltmak ve şehirlerdeki vatandaşlara hizmet sunmak için IBM'in önemli bir stratejisi olan akıllı şehirler kapsamında yeni nesil bilgi teknolojisi olan algılayıcıları ve teçhizatları hastanelere, demiryollarına, köprülere, tünellere, yollara, binalara, su sistemlerine, barajlara ve boru hatlarına İnternet aracılığıyla uygulanmaya başlanmasıyla (Zhang, 2010) akıllı şehir kavramı önem kazanmaya başlamıştır.

Akıllı şehir kavramı teknolojinin şehir ile bütünleştiği bir ortamı ifade etmektedir. $\mathrm{Bu}$ teknoloji, vatandaşların yaşam kalitesini iyileştirmek ve aynı zamanda enerji kullanımını azaltmak ve daha iyi trafik izleme gibi şehir hizmetleri verimliliğini artırmak için şehrin sosyal bileşenleri ile sinerji oluşturmaktadır (Vicini vd., 2012: 59). Akıllı şehirler bilgi ve iletişim teknolojilerini ve interneti kullanarak vatandaşlarına çeşitli hizmetler sunmakta ve toplumsal sorunlara çözüm bulabilmektedir. Örnek olarak bir şehrin bilgi ve iletişim teknolojileri ile yazılımın gerçekleştirdiği gerçek zamanlı bir ulaşım programı akıllı telefon aracılığıyla vatandaşlarına hizmetine sunarak vatandaşlarına toplu ulaşım araçlarının anlık olarak nerede olduğu bilgisini vermektedir. Böylelikle vatandaşlar ve turistler toplu taşım araçlarına yönlendirilerek çevre kirliliği ve trafik sorunları da azaltılmış olur.

Turizm sektöründe bilginin yoğun kullanımı ile beraber bilgi ve iletişim teknolojilerine bağımlılığı göz önüne alındığında (Koo vd., 2015, 100; Benckendorff vd. 2014) akıllı sıfatının turizm için kullanılması da kaçınıımaz olmuştur. Hatta akıllı turizmi gerçekleştirmek için dünyada çok çeşitli kurumsal destek bulunmaktadır. Özellikle Asya'da, akıllı turizm gündemi oluşturmak için büyük çabalar sarf edilmiştir. Çin ve Güney Kore akıllı turizmi destekleyen teknolojik alt yapının oluşturulmasına odaklanan girişimlere ciddi miktarlarda fonlar sağlamaktadır (Hwang vd. 2015, 164). Akıllı uygulamaların vatandaşlara ve turistlere kullanıcı intiyaçlarını öngörüp cazibe merkezleri, yemek ve içecek ile ilgili tavsiyelerde bulunmak; konuma dayalı ve özelleştirilmiş etkileşimli hizmetler sunarak deneyimleri artırmak gibi amaçları bulunmaktadır. Ayrıca akıllı uygulamalar ile turistler seyahat deneyimlerini paylaşabilmekte ve böylelikle diğer turistlere karar verme sürecinde yardımcı olabilmektedir (Yoo vd., 2015: 240). Bundan dolayı çalışmanın amacı Türkiye'de önemli bir turizm destinasyonu olan Antalya destinasyonunun uygulamalarını akıllı turizm destinasyonları kapsamında incelemek olarak belirlenmiştir. Çalışma sonucunda Antalya destinasyonunun Türkiye'nin akıllı bir turizm destinasyonu olması ve turistler tarafından Antalya destinasyonunun akıllı turizm destinasyonu olarak tanınması için önerilerde bulunulmuştur.

\section{Literatür Taraması}

\subsection{Akıllı Şehir}

Literatürde çok çeşitli akıllı şehir tanımı mevcuttur. Akıllı şehir kavramı popüler bir kavram olarak bilinirken, bu kavram dünyada farklı isimlerle ve farklı koşullarda 
kullanıldığı için akıllı sıfatını diğer alternatif sıfatlarla değiştirerek oluşturulan bir dizi kavram bulunmaktadır. Washburn vd. (2010: 2) akıllı bilgisayar teknolojilerinin kullanımına açık bir vurgu yaparak akıllı şehri kavramsallaştırmaktadır. Giffinger vd. (2007: 12) akıllı şehri ekonomi, insanlar, yönetişim, hareketlilik ortamı ve yaşamdaki performansına vurgu yaparak tanımlamaktadır. Rios'un (2008: 5) mimari bir objektife dayanan yaklaşımı akıllı şehri ilham veren; kültürün, bilginin ve hayatın paylaşıldığı bir şehir olarak görmektedir ve vatandaşlarını kendi yaşamlarında yaratıcılığa yönlendirmektedir.

Tablo 1: Akıllı Şehir Tanımları

\begin{tabular}{|c|c|c|}
\hline YII & Yazar (lar) & Tanım \\
\hline 2008 & Dirks ve Keeling & $\begin{array}{l}\text { Akıllı bir şehir faaliyetlerini kontrol etmek ve sınılı } \\
\text { kaynakların kullanımını optimize etmek için birbirine bağlı } \\
\text { tüm bilgiyi en iyi şekilde kullanan şehirdir. }\end{array}$ \\
\hline 2009 & Caragliu ve diğerleri & $\begin{array}{l}\text { Insan ve sosyal sermayeye yatııı yapan, geleneksel } \\
\text { (ulaşım) ve modern (BiT) iletişim altyapısını kurmuş, } \\
\text { sürdürülebilir, ekonomik büyüme ve yüksek yaşam } \\
\text { kalitesini sağlamış, doğal kaynakların yönetimini katıımcı } \\
\text { yönetişimle yapan şehirdir. }\end{array}$ \\
\hline 2012 & Schaffers vd. & 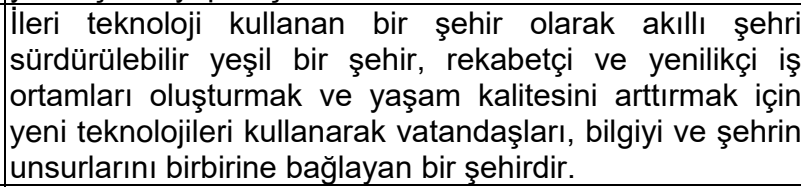 \\
\hline 2013 & Berst & $\begin{array}{l}\text { Akıllı bir şehir, bütün şehir faaliyetlerinde dijital } \\
\text { teknolojinin bulunduğu bir şehirdir. }\end{array}$ \\
\hline 2013 & Meijer ve Bolivar & $\begin{array}{l}\text { Insan ve toplumsal sermayeye, geleneksel ve modern } \\
\text { iletişim altyapılarına yatırım yaptığında, doğal } \\
\text { kaynakların yönetimi ile sürdürülebilir ekonomik } \\
\text { büyümeyi ve yaşam kalitesini artırabilen akıllı sıfatıyla } \\
\text { nitelendirilen şehirdir. }\end{array}$ \\
\hline 2013 & $\begin{array}{l}\text { İngiltere İs, Yenilik ve } \\
\text { Yetenekler Politikaları } \\
\text { Bakanlığı (UK Department } \\
\text { of Business, Innovation } \\
\text { and Skills) }\end{array}$ & $\begin{array}{l}\text { Akıllı şehirleri vatandaş katııımının, altyapının, sosyal } \\
\text { sermayenin ve dijital teknolojilerin şehirleri daha } \\
\text { yaşanabilir, esnek ve sorunlara daha iyi çözüm } \\
\text { üretebilecek bir şehre dönüştürme süreci olarak } \\
\text { görmektedir. }\end{array}$ \\
\hline 2014 & $\begin{array}{l}\text { Uluslararası Standartlar } \\
\text { Enstitüsü (ISO) }\end{array}$ & $\begin{array}{l}\text { Şehrin planlamasını, yönetimini, inşasını ve akıllı } \\
\text { hizmetleri kolaylaştıracak nesnelerin interneti, butut } \\
\text { biliş̧im, büyük veri ve entegre coğrafi bilgi sistemleri gibi } \\
\text { yeni nesil bilgi iletişim teknolojilerinin uygulandığı yeni bir } \\
\text { kavram ve yeni bir modeldir. }\end{array}$ \\
\hline 2014 & $\begin{array}{l}\text { İngiliz Standartları } \\
\text { Enstitüsü (BSI) }\end{array}$ & $\begin{array}{l}\text { Akııllı şehir vatandaşlarına sürdürülebilir bir gelecek } \\
\text { sağlamak için fiziksel, dijital ve insan sistemlerinin çevre } \\
\text { ile bütünleşmesini sağlayabilen bir şehirdir. }\end{array}$ \\
\hline 2015 & Hint Hükümeti & $\begin{array}{l}\text { Akıllı şehir, eğitim seviyeleri, becerileri ya da gelir } \\
\text { düzeyleri ne olursa olsun, ekonomik faaliyetler ve } \\
\text { istihdam fırsatları açısından vatandaşlarının geniş bir } \\
\text { kesimine sürdürülebilirlik getiren şehirdir. }\end{array}$ \\
\hline 2015 & Akıllı Şehirler Konseyi & $\begin{array}{l}\text { Bilgi ve iletişim teknolojilerini şehrin yaşanabilirliğini, } \\
\text { çalışılabilirliğini ve sürdürülebilirliğini } \\
\text { kullanan şehirdir. }\end{array}$ \\
\hline 2015 & Avrupa Komisyonu & $\begin{array}{l}\text { Geleneksel hizmetlerin ve ağların sayısal ve } \\
\text { telekomünikasyon teknolojileri kullanılarak, yaşayanların } \\
\text { ve işyerlerinin fayda sağlayacağı şekilde daha verimli } \\
\text { hale getirildiği şehirdir. }\end{array}$ \\
\hline
\end{tabular}


Pazarlama dilinde ise akıllı kavramı kullanıcı merkezli bir bakış açısıdır ve bu da akıllı ürün veya hizmetin daha çok kullanıcı dostu olmasını sağlamaktadır (Nam ve Pardo, 2011, 283). Akıllı şehirler konsepti vatandaşların yaşam kalitesini artırıak ve şehir hizmetlerinin verimliliğini iyileştirmek için sosyal bileşenleriyle sinerji yaratmaya çalışan teknoloji ile iç içe olan ekosistem ile ilişkilendirilmektedir (Egger, 2013: 128). Akıllı şehirler ile ilgili literatürde yer alan tanımlar Tablo 1'de verilmiştir.

Akıllı şehir tanımları dikkate alındığında Bilgi ve İletişim Teknolojilerinin (BiT) akıllı şehirler geliştirmek için bir anahtar olduğu söylenebilir. Tablo 1'deki tanımlar incelendiğinde akıllı şehir daha yaşanabilir, daha sürdürülebilir, daha verimli olması amacıyla bilgi iletişim teknolojilerinin sağladığı çözümleri odağına insanı alarak, ilgili tüm paydaşların ve kurumların sahipliğinde, kişisel verinin gizliliği ve diğer etik kuralları ihlal etmeden, katılımcı ve şeffaf bir şekilde uygulayabilen, kendini sürekli geliştiren ve öğrenen şehir şeklinde tanımlanabilir (Türkiye Bilişim Vakfı, 2016).

Chourabi vd. (2012, 2290) akıllı bir şehrin altı özelliğinin akıllı ekonomi, akıllı insanlar, akıllı yönetişim, akıllı hareketlilik, akıllı çevre ve akıllı yaşam olduğunu belirtmiştir. İnsan sermayesine yatırım, yeterli düzeyde hükümet katılımı ve şehir genelinde bilgilerin doğru şekilde yaygınlaştırılmasını destekleyen altyapı ile sürdürülebilir ekonomik büyüme ve yüksek yaşam kalitesi sağlayan bir şehir akıllı olarak sınıflandırılabilir (Caragliu vd., 2009, 50). Bundan dolayı akıllı destinasyonlar insan sermayesi, altyapı / enformasyon yapısı ve bilgi üzerine yoğunlaşmalıdır (Schaffers vd., 2012).

Cohen (2012) akıllı şehir stratejilerinin geliştirilmesini desteklemek ve ilerlemeyi kontrol için bir araç olarak 'Akıllı Şehir Tekerleği' geliştirmiştir.

\section{Şekil 1: Akıllı Şehrin Temel Bileşenleri (Akıllı Şehir Tekerleği)}

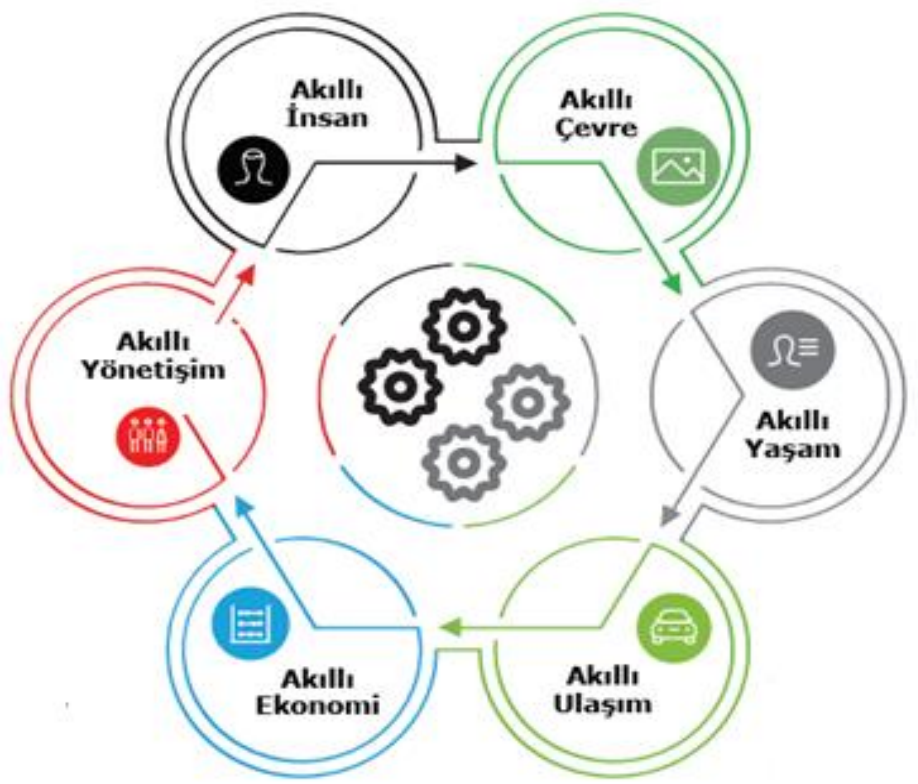

Kaynak: (Cohen, 2012)

$\mathrm{Bu}$ tekerlekte Cohen (2012) akıllııık boyutlarının her biri için birkaç unsur tanımlamıştır ve altı akıllılık boyutu belirlemiştir; 
- Akıllı Yönetişim: (Smart Governance): Veri paylaşımını ve halkın katılımını destekleyerek şehir yönetiminin modernizasyonu yoluyla yönetişim sistemleri içinde şeffaflık ile ilgilenen 'Akıllı Yönetişim' boyutunun alt boyutları çevirimiçi hizmetler, altyapı ve açık devlettir. Karar vericiler teknolojiyle tüm paydaşların çıkarlarını göz önünde bulundurup kaynakların daha akıllı bir şekilde kullanılarak uzun vadeli toplumsal faydanın sağlanması için çalışacma hedeflenmektedir.

- Akıllı Çevre: (Smart Environment): Mevcut kaynakların sürdürülebilir yönetimine olanak sağlayan enerji yönetimi ile ilgili 'Akıllı Çevre' boyutunun alt boyutları akıllı binalar, kaynak yönetimi ve kentsel planlamadır. Teknoloji yardımıyla çevre ve doğanın sürdürülebeilirliği sağlananırken, yeşil alanlar ve su kaynakları kontrol eilmesi hedeflenmektedir.

- Akıllı Mobilite: (Smart Mobility): Şehir içinden ve şehir dışından erişilebilirliği ve modern ulaşım sistemlerinin mevcudiyeti ile ilgili olan 'Akılı Hareketlilik' boyutunun alt boyutları karma ulaşım modeli, temiz ve motorsuz mobilite, bütünleşik BiT'tir. Toplu taşıma alt yapısının en optimal haliyle kullanılması sayesinde trafik sıkışıklığı ve hava kirliliği gibi şehirlerin temel problemlerinin azaltılması hedeflenmektedir.

- Akıllı Ekonomi: (Smart Economy): Dijital teknoloji temeline dayanan ekonomik stratejilerin uygulanmasına ilişkin 'Akıllı Ekonomi' boyutunun alt boyutları fırsat, üretkenlik ve yerel \& küresel birbirine bağlanabilirliktir. Kaldıraç etkisiyle mevcut kaynaklar daha etkin kullanılması, finansman ve insan kaynaklarına veya zamana dair darboğazların aşılması hedeflenmektedir.

- Akıllı İnsanlar (Smart People): Şehrin insan sermayesinin nitelik seviyesine bağlı 'Akıllı İnsan' boyutunun alt boyutları eğitim, katılımcı toplum, yaratıcılık İnsalar, sosyal hayatta daha çok katılmakta, çoğulculuk ve şehir kültürü yaşam boyu devam eden bir öğrenme sürecine dönüşmektedir. Yaratıcılık ve açık fikirliliğin teşvik edilmesi hedeflenmektedir.

- Akılı Yaşam: (Smart Living): Sağıklı çevre, sosyal bütünlük, turistik şehir, kültürel ve eğitimsel hizmetler açısından ölçülebilen yaşam kalitesini içermektedir. 'Akıllı Yaşam' boyutunun alt boyutları sağlık, güvenlik, kültür ve memnuniyettir. Barınma, güvenlik, sağlık, eğitim, boş zaman faaliyetleri gibi ihtiyaçların kapsamının teknolojiyle beraber belirlenmekte, sosyal bütünlüğün sağlanması hedeflenmektedir.

\subsection{Akıllı Turizm}

Gretzel vd. (2015: 181) akıllı turizmi fiziki altyapı, sosyal bağlantılar, devlet/örgüt kaynakları ve insan aklından ortaya çıkan verilerin toplanması için bir destinasyondaki çabalar ile desteklenen turizm olarak tanımlamaktadır. Sigala (2015: 815) akıllı turizmin beş pazar unsurunun (döviz, pazar aktörleri, pazar yapısı, pazar kurumları ve pazar uygulamaları) tamamının veya bir kısmının değişmesi ile oluştuğunu ifade etmiştir.

Morabito (2015: 66), büyük bir veri ile çalışılan akıllı çevrelerde turizm işletmelerinin iş modellerinin dokuz unsurunu etkilediğini belirtmiştir. Bu unsurlar; müşteri bölümleri, değer önermeleri, kanallar, müşteri ilişkileri, gelir akışları, temel kaynaklar, temel faaliyetler, temel ortaklıklar ve maliyet yapısı. Bundan dolayı iş modellerini tanımlamak için turizm işletmeleri şu tasarım unsurlarını belirlemelidirler, aktörün kazanç mantığı, aktörün değer ağı, aktörün sahip olduğu kaynaklar ve yetenekler, aktörün stratejik kararları ve müşteri değer yaratma (Nenonen ve Storbacka, 2010:45). Turizm bağlamında akıllı teknolojiler müşteri deneyimlerini değiştirmekte ve yaratıcı turizm iş modellerinin ortaya çıkmasına neden olmaktadır. Bulut bilişim, büyük veriler, mobil uygulamalar, konuma dayalı hizmetler, coğrafi etiket hizmetleri, işaret feneri teknolojisi, sanal gerçeklik, güçlendirilmiş gerçeklik ve sosyal ağ hizmetleri turizm deneyimlerini ve hizmetlerini geliştiren akıllı teknolojilerin en önde gelen örnekleridir (Wang vd., 2012: 374). 
Şekil 2'de şematik olarak gösterildiği gibi Zhang vd.'ne (2012) göre akıllı turizm sistemi beş unsurdan oluşmaktadır: bilgi değişim merkezi, turistler, hükümet, doğal alanlar ve iş. Genel olarak, turistler bilgi değişim merkezine bilet arama, bilet satın alma, rezervasyon, sosyal iletişim vs. gibi talepler göndermektedir. Bilgi değişim merkezi daha sonra talep edilen bilgi veya sonuçları talep edene göndermektedir. Bilgi değişim merkezi doğal alanlar kaynaklarını gerçek zamanlı olarak izlemekle de yükümlüdür. Günlük ziyaret verilerinin istatistikleri yönetimi analiz etmek ve arşivlemek için bilgi alışverişi merkezine bildirilmelidir. Öte yandan, istatistikî veriler bir sonraki politikaların belirlenmesi için turizm idaresinde hükümet yetkililerine ulaştırılabilir. Turizm işletmeleri, oteller, restoranlar ve eğlence işletmeleri gibi işletmeler bilgi değişim merkezinden turistlere reklam veya tanıtım göndermelerini isteyebilmektedir (Zhang vd., 2012).

Şekil 2: Akıllı Turizm Yapısı

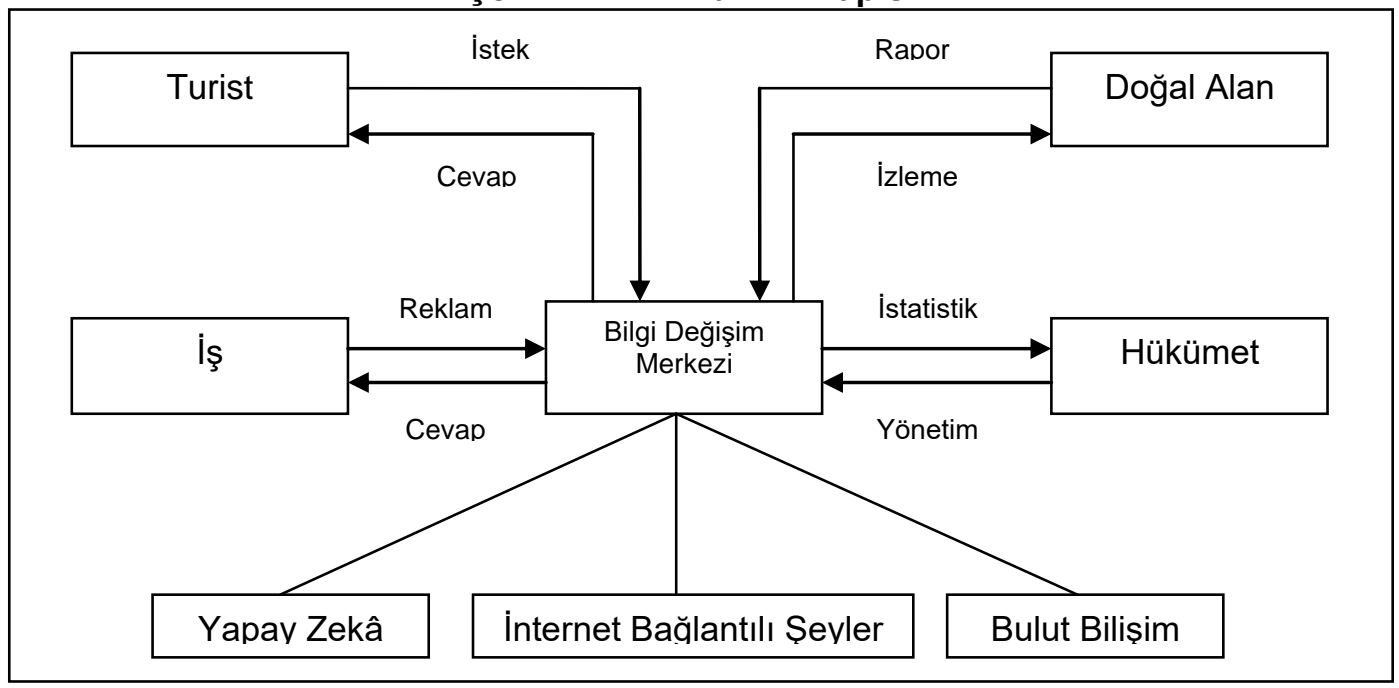

Kaynak: (Zhang vd., 2012).

Akıllı turizm bilgi ve iletişim teknolojileri tarafından desteklenen çoklu bileşenleri ve akıllı katmanları kapsamaktadır (Gretzel vd., 2015: 181). Bu bileşenler Şekil 3'te verilmiştir. Akıllı turizm akıllı destinasyonlar anlamına da gelmektedir. Çünkü akıllı destinasyon ilkelerini kentsel veya kırsal alanlara uygularken sadece vatandaşları değil aynı zamanda turistlerin de hareketliliği, kaynak kullanılabilirliği, kaynakların sürdürülebilirliği ve yaşam/ziyaret kalitesini de hesaba katmaktadır. Lopez de Avila (2015) akıllı turizm destinasyonunu yenilikçi, turistik alanların sürdürülebilir kalkınmasını sağlayan, son teknoloji ürün altyapısı üzerine inşa edilmiş, herkes tarafından erişilebilen ve hem vatandaşların yaşam kalitesini hem de turistlerin deneyim kalitesini arttıran destinasyon olarak tanımlamaktadır.

Şekil 3: Akıllı Turizmin Bileşenleri ve Katmanları

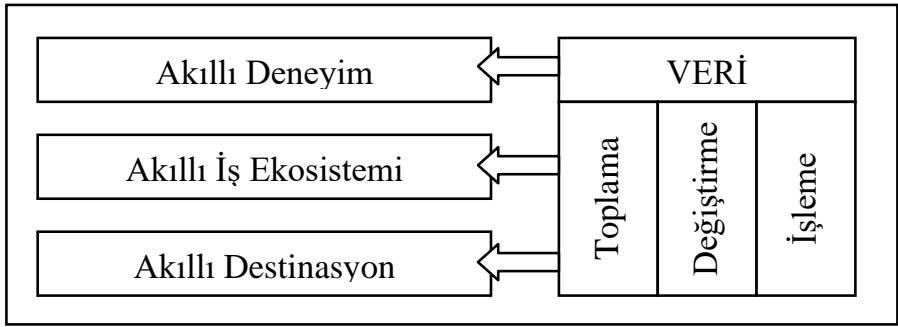

Kaynak: (Gretzel vd., 2015: 181). 
Washburn vd.'ne (2010: 2) göre akıllı turizmde teknoloji bireysel bilgi sistemleri yerine altyapı olarak görülmektedir ve gerçek dünyada gerçek zamanlı farkındalık sağlayarak insanların alternatifler hakkında daha akıllı kararlar almalarını sağlamak için donanım, yazılım ve ağ teknolojilerini bütünleştiren çeşitli akıllı bilgi işlem teknolojilerini kapsamaktadır. Bunun yanı sıra iş süreçleri ve iş performansları en üst düzeye teknoloji ile çıkarılabilmektedir (Washburn vd., 2010: 2). Günümüzde mobil cihazların, özellikle de akıllı telefonun ve sayısız uygulamanın yaygın kullanımı, eşi benzeri görülmemiş bir bağlantı ve İnternet'e her yerden erişim imkânı sunmaktadır (Wang ve Xiang, 2012: 309). Bu nedenle Bulut Bilişim ve Son Kullanıcı İnternet Hizmet Sistemleri gibi mobil erişimi destekleyen birçok teknolojik gelişme akıllı turizm stratejilerini gerçekleştirmek için bir araç olarak kullanılmaya başlanmıştır (Gretzel vd. 2015, 182).

\section{Akıllı Turizm Destinasyonu}

Akıllı turizm destinasyonu geliştirmek için önemli olan üç tür bilgi ve iletişim teknolojisi bulunmaktadır: Bulut Bilişim, İnternet Bağlantılı Şeyler ve Son Kullanıcı İnternet Hizmet Sistemleri (Zhang vd., 2012). Bulut bilişim hizmetleri belirli ağlar aracılığıyla web platformlarına ve veri saklama alanlarına erişmenin kolay yollarını sağlamak için tasarlanmıştır. Bulut bilişim hizmetlerinin kullanımı sabit maliyetleri azaltmakta ve intiyaçlara göre değişen maliyet olarak ortaya çıkmaktadır (Etro, 2009, 181). Aynı zamanda Akıllı turizm destinasyonları projelerinin geliştirilmesi için temel olan bilgi paylaşımını da sağlamaktadır. İnternet bağlantılı şeyler terimi ise ilk olarak 1999'da Kevin Ashton (MIT) tarafından kullanılmıştır. Kevin Ashton internet bağlantılı şeyler terimini akıllı nesneleri tanımlamak, bulmak, yönetmek ve izlemek için herhangi bir zamanda herhangi bir şeyi birbirine bağlayan bir ağ olarak tanımlamaktadır (Mingjun vd., 2012: 261). İnternet bağlantılı şeyler akıllı destinasyonları bilgi, analiz ve ayrıca otomasyon ve kontrol açısından destekleyebilmektedir (Chui vd., 2010). Akıllı bir destinasyonun üçüncü bileşeni son kullanıcı internet hizmet sistemleridir. Son kullanıcı internet hizmet sistemleri bulut bilişim ve internet bağlantılı şeylerin birleşimiyle desteklenen çeşitli düzeylerdeki uygulamalardır (Mingjun vd., 2012: 262).

Tablo 2: Akıllı Turizm Destinasyonlarında Turizm Uygulamaları

\begin{tabular}{|c|c|c|c|}
\hline No & Akıllı turizm destinasyonlarında turizm uygulamaları & $\begin{array}{l}\text { Destinasyon } \\
\text { Bileşenleri }\end{array}$ & $\begin{array}{l}\text { Akıllı Turizm } \\
\text { Destinasyon } \\
\text { Boyutları }\end{array}$ \\
\hline 1 & $\begin{array}{l}\text { Artırılmış gerçeklik turistlere turizm mekanlarının } \\
\text { dijital rekreasyonunu deneyimlemesine olanak } \\
\text { tanıyabilir (Chillon, 2012) }\end{array}$ & Çekicilik & $\begin{array}{l}\text { Akıllı Insanlar, } \\
\text { Akıllı Hareketlilik }\end{array}$ \\
\hline 2 & $\begin{array}{l}\text { Araç takip sistemi ulaşım ağının gerçek zamanlı } \\
\text { bilgisini sağlamakta ve son kullanıcı cihazlarıyla } \\
\text { paylaşılabilir (Arup, 2010) }\end{array}$ & Erişilebilirlik & $\begin{array}{l}\text { Akıllı Yaşam, } \\
\text { Akıllı Hareketlilik }\end{array}$ \\
\hline 3 & $\begin{array}{l}\text { Oteller bina için enerji talebini tahmin edebilmeli ve } \\
\text { çevre yönetimi temelinde enerji sağlamalıdır (Metric } \\
\text { Stream, 2013) }\end{array}$ & Olanaklar & Akıllı Çevre \\
\hline 4 & $\begin{array}{l}\text { Elektronik seyahat rehberi gibi çeşitli hizmetleri } \\
\text { sağlayan ve birçok mevcut paket sunan çok dilli bir } \\
\text { uygulama (Ürdün, 2011) }\end{array}$ & $\begin{array}{l}\text { Mevcut } \\
\text { Paketler }\end{array}$ & $\begin{array}{l}\text { Akıllı İnsanlar, } \\
\text { Akıllı Hareketlilik }\end{array}$ \\
\hline 5 & $\begin{array}{l}\text { Mobil cihazlar aracılığıyla yakındaki ilgi çekici yerler } \\
\text { hakkındaki bilgilere erişmek için NFC etiketleri ve } \\
\text { QR kodları (GSMA, 2012) }\end{array}$ & Etkinlikler & Akıllı Hareketlilik \\
\hline 6 & $\begin{array}{l}\text { Turistlerin şikâyetlerini SMS veya mobil gibi çeşitli } \\
\text { Bilgi ve Iletişim Teknolojileri kanalları tarafından } \\
\text { desteklenen Şikâyet Yönetimi Sistemi aracılığıyla } \\
\text { iletebildiği ve bunları uygun görevlilere yönlendiren } \\
\text { uygulamalar (Metrik Stream, 2013) }\end{array}$ & $\begin{array}{l}\text { Yan } \\
\text { Hizmetler }\end{array}$ & Akıllı Yaşam \\
\hline
\end{tabular}

Kaynak: (Buhalis ve Amaranggana, 2013: 559). 
Akıllı turizm destinasyonları Cohen (2012) tarafından tanımlanan akıllı destinasyon bileşenleri içinde yer alan turizm uygulamalarından uygun olanları uygulamalıdır. Tablo 2'de destinasyon bileşenleri (çekicilikler, erişilebilirlik, olanaklar, mevcut paketler, etkinlikler, yan hizmetler) ve Cohen'in (2012) akıllı destinasyon boyutlarından meydana gelmiş olan akıllı turizm destinasyon boyutları kullanılıp bir karma yapılarak turizm uygulamaları oluşturulabilir ve akıllı turizm destinasyonlarında kullanılabilir (Buhalis ve Amaranggana, 2013, 558).

Buhalis ve Amaranggana (2015) ise akıllı bir turizmin turizm deneyimine nasıl katkıda bulunabileceğini gösteren bir model geliştirmiştir. Şekil 4 akıllı turizm destinasyonunun turist deneyimini nası artırabildiğini göstermektedir.

Şekil 4: Akıllı Turizm Destinasyonunun Turizm Deneyimine Katkısı

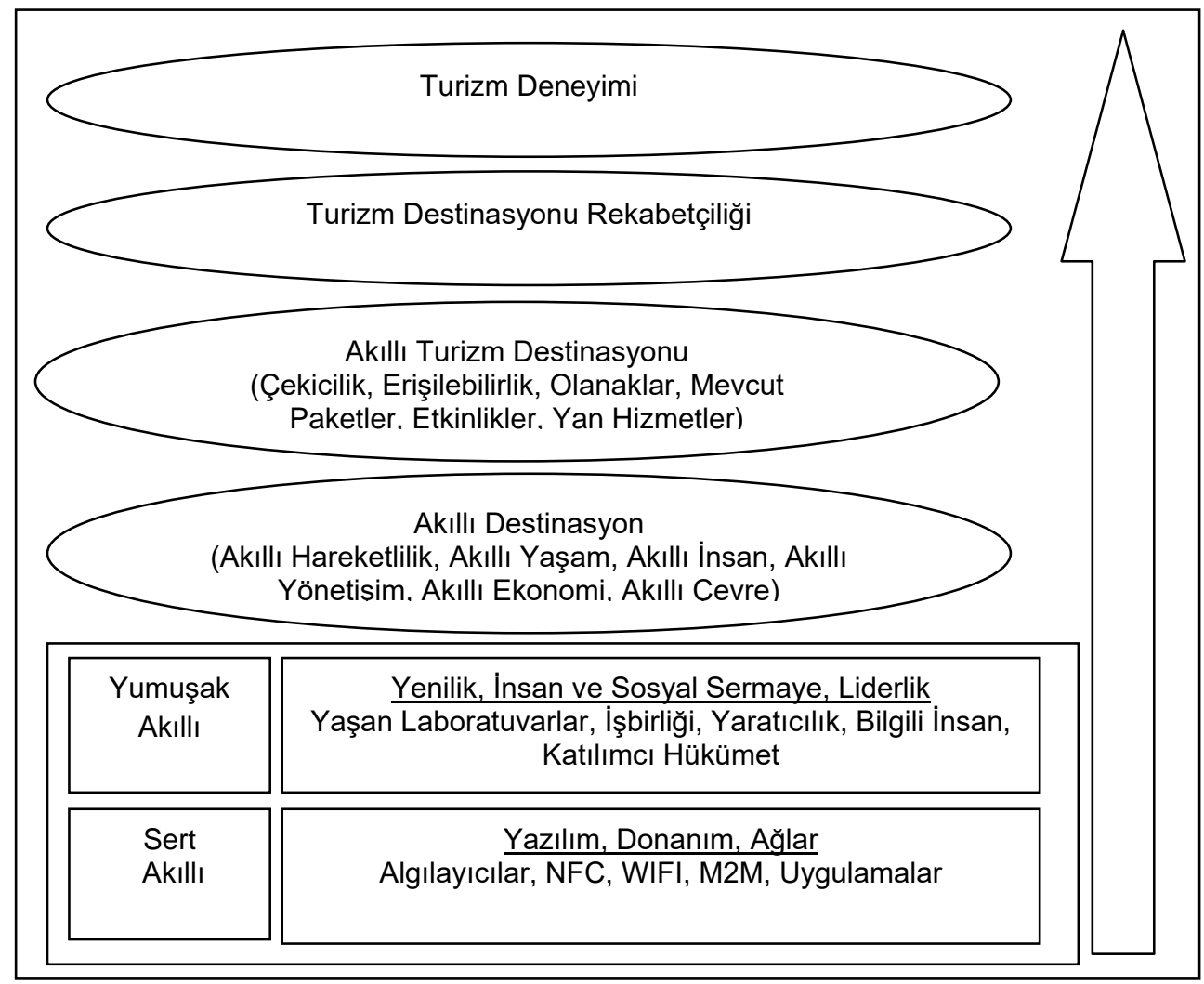

Kaynak: (Buhalis ve Amaranggana, 2015)

Buhalis ve Amaranggana'nın (2015) geliştirdiği model hayatımızdın İnternet bağlantı şeyler ile nasıl akıllı olmaya başladığını göstermektedir. Bu basamak daha sonra akıllı destinasyona, akıllı destinasyonda da akıllı turizm destinasyonuna (bu basamakta turizm ile ilgili önemli unsurlar dikkate alınmakta) geçmektedir. Bütün bunlar turizm rekabetçiliği ve turizm deneyimine yol açmaktadır.

\section{Araştırmanın Yöntemi}

Antalya Büyükşehir Belediyesi son dönemlerde akıllı kent olma yolunda çalışmalar yapması nedeniyle çalışmanın uygulama kısmında Antalya destinasyonu örnek olarak seçilmiş akıllı turizm destinasyonu uygulamaları incelenmiştir. Çalışmada Antalya'nın 
akıllı turizm destinasyonu uygulamalarını incelenerek tespit edilen bulgular ışığında, konuyla ilgilenen araştırmacılara ve sektöre akıllı turizm uygulamalarının geliştirilmesi için öneriler sunulması amaçlanmıştır. Ayrıca çalışmanın, akıllı turizm destinasyonu planlaması ve akılı turizm destinasyonu uygulamaları konularında kamu, özel kesim ve destinasyon yöneticilerine, turizm sektöründe faaliyet gösteren işletmelere yardımcı olması amaçlamaktadır.

Çalışmada nitel araştırma yöntemlerinden durum çalışması (örnek olay) kullanılmıştır. Nitel araştırma, gözlem, görüşme ve doküman analizi gibi nitel veri toplama tekniklerinin kullanıldığı, algıların ve olayların doğal ortamda gerçekçi ve bütüncül bir biçimde ortaya konmasına yönelik nitel bir sürecin izlendiği araştırma olarak tanımlamaktadır (Yıldırım ve Şimşek, 2008, 39). Nitel araştırma, disiplinler arası bütüncül bir bakış açısını esas alarak, araştırma problemini yorumlayıcı bir yaklaşımla incelemeyi benimseyen bir yöntemdir (Altunışık ve Diğerleri, 2010:302). Nitel araştırma desenlerinden biri olan durum çalışması sosyal bilimlerde yapılan araştırmalarda kullanılan bir araştırma yöntemidir. Durum çalışmasında herhangi bir olay, birey ya da sürecin verilerine dayalı derinlemesine inceleme yapılmaktadır (Creswell, 2007). Durum çalışması, güncel bir olguyu kendi gerçek yaşam çevresi içinde çalışan, olgu ve içinde bulunduğu çevre arasındaki sınırların kesin hatlarıyla belirgin olmadığı ve birden fazla kanıt veya veri kaynağının mevcut olduğu durumlarda kullanılan, bir araştırma yöntemidir (Yıldırım ve Şimşek, 2003: 190). Creswell (2007)'ye göre durum çalışması; araştırmacının zaman içerisinde sınırlandırımış bir veya birkaç durumu çoklu kaynakları içeren veri toplama araçları (gözlemler, görüşmeler, görselişitseller, dokümanlar, raporlar) ile derinlemesine incelediği, durumların ve duruma bağlı temaların tanımlandığı nitel bir araştırma yaklaşımıdır. Bu çalışmada doküman inceleme yöntemi kullanılmıştır. Araştırma kapsamında incelenen dokümanlar Türkiye Akıllı Şehirler Değerlendirme Raporu, Akıllı Şehirler Yol Haritası, Antalya Büyükşehir Belediyesi Akıllı Şehir Çalışmaları, Antalya Büyükşehir Belediyesinin konu ile ilgili bildirimleri, Kamu Teknolojileri Platformu Akıllı Kentler Masabaşı Araştırmasıdır. Ayrıca Antalya Büyükşehir Belediyesinin myAntalya ve AntalyaKart uygulamaları akıllı telefona indirilerek detaylı olarak incelenmiştir. Araştırmacılar turistlerin yoğun olarak bulunduğu bölgelerde bu uygulamaların çalışmalarını incelenip, faydaları ve bu faydaların arttırıması yönünde katıımcı gözlemci olarak kullanımda bulunmuşlardır.

\section{Bulgular}

Akıllı şehir projesi ile Antalya'da teknolojide, turizmde, ulaştırmada, sağlıkta, güvenlikte, belediye hizmetlerinde yeni bir dönem başlamıştır. Antalya'da bu yeni dönemde akıllı turizm noktaları, şehir merkezinde ücretsiz wi-fi, insansız hizmet noktaları, elektronik trafik kontrol sistemi, akıllı toplu ulaşım sistemi, akıllı sağlık hizmeti, engelsiz SMS sistemi, akıllı çevre ve akıllı enerji sistemleri kurulması hedeflenmektedir. Ayrıca turistlere birkaç dilde interaktif bilgi desteği sağlayacak kiosklar kurulması Antalya'nın akıllı turizm hedefleri arasındadır. Turistler kiosklarla veya akıllı telefonlarla şehir hakkında, işletmeler hakkında istediği bilgilere hemen ulaşacaktır. Tarihi yerler, mağazalar, restoranlar, kafeler ve daha birçok bilgiye kolayca erişebileceklerdir. Turizmde önemli bir destinasyon olan ve her yıl milyonlarca turisti ağırlayan Antalya'da akıllı şehir uygulamaları turizme de önemli katkı sağlayacaktır. Çalışmada yapılana incelemeler sonucunda Antalya'nın akıllı turizm uygulamalarının çok başında olduğu söylenebilir. Ancak Antalya destinasyonu akıllı turizm hedeflerini tamamladığı zaman diğer önemli turizm destinasyonlarında olduğu gibi turizme önemli katkılarının olacağı düşünülmektedir. 


\subsection{Akılı Turizm Destinasyonu Kapsamında Antalya}

2015 yılının ilk aylarında Antalya Büyükşehir Belediyesi turizmde, ulaşımda, sağlıkta, güvenlikte, belediye hizmetlerinde akıllı şehir olmak için proje başlattığını kamuoyuna duyurmuştur. Ayrıca proje kapsamında ücretsiz internet, elektronik trafik kontrol sistemi, akıllı toplu ulaşım sistemi, akıllı turizm noktaları, insansız hizmet noktaları, akıllı sağlık hizmeti, engelsiz SMS sistemi, akıllı çevre ve akıllı enerji sistemlerinin kurulacağı açıklanmıştır (http://www.antalya.bel.tr).

Akıllı turizm destinasyonu olma kapsamında turistlerin en çok tercih ettiği alanlardan olan Cumhuriyet Meydanı, Kapalıyol ve plajlarda toplam sekiz noktada ücretsiz internet noktası oluşturulmuş ve hizmete sunulmuştur. İnsansız hizmet noktaları kapsamında ise belediye ile ilgili hizmetler çeşitli yerlere yerleştirilen kiosklar ile yapılmaya başlamıştır. Kronik hastalara dağıtılan panik butonu ile ambulans çağırma hizmeti ile de Antalya destinasyonu akıllı sağlık hizmeti sunmaya başlamıştır. Akıllı sağlık hizmeti kapsamında akıllı ev telefonları aracılığıyla kronik hastaların tansiyon, şeker ve nabız ölçümlerinin takibe alınması uygulaması hizmete sunulmuştur (http://www.antalya.bel.tr). Ayrıca belediye otobüslerinde de kullanıcılar iletişim bilgileri ile kayıt oluşturarak ücretsiz internet erişimine sahip olabilmektedir. Elektronik trafik kontrol sistemi kapsamında ise trafik lambaları araç yoğunluğuna göre yanacak şekilde Antalya destinasyonunun bir baştan diğer başına kadar yoğun kavşaklarda akıllı sinyalizasyon sistemine geçiş yapılmıştır. Sağlanan akıllı trafik kontrol sistemi ile itfaiye ve ambulansların geçiş önceliği de kolaylaştırılmıştır. Akıllı toplu ulaşım kapsamında ise Tablo 2'de belirtilen Antalyakart uygulaması hayata geçirilmiştir. Ayrıca yoğun olarak kullanılan duraklara durağa yaklaşan otobüsleri gösteren panolar ve toplu ulaşım kartlarına kolaylıkla bakiye yüklenen kiosklar yerleştirilmiştir.

Buhalis ve Amaranggana $(2013,559)$ tarafından geliştirilen akıllı turizm destinasyonu uygulamaları boyutları kapsamında Antalya destinasyonu için uygulanmıştır ve Tablo 3'de özetlenmiştir.

Tablo 3: Antalya Destinasyonu Akıllı Turizm Uygulamaları

\begin{tabular}{|l|l|l|l|}
\hline No & $\begin{array}{l}\text { Destinasyon } \\
\text { Bileşenleri }\end{array}$ & $\begin{array}{l}\text { Akıllı Turizm Destinasyon } \\
\text { Boyutları }\end{array}$ & $\begin{array}{l}\text { Antalya Destinasyonundaki } \\
\text { Uygulamalar }\end{array}$ \\
\hline 1 & Çekicilik & $\begin{array}{l}\text { Akıllı İnsanlar, } \\
\text { Akıllı Hareketlilik }\end{array}$ & $\begin{array}{l}\text { myAntalya, antalyakart, ICF } \\
\text { Airport Mobile }\end{array}$ \\
\hline 2 & Erişilebilirlik & $\begin{array}{l}\text { Akıllı Yaşam, } \\
\text { Akıllı Hareketlilik }\end{array}$ & myAntalya \\
\hline 3 & Olanaklar & Akıllı Çevre & $\begin{array}{l}\text { Akıllı İnsanlar, } \\
\text { Akıllı Hareketlilik }\end{array}$ \\
\hline 4 & Mevcut Paketler & Akıllı Hareketlilik & myAntalyalya, www.antalya.bel.tr \\
\hline 5 & Etkinlikler & Akıllı Yaşam & \\
\hline 6 & Yan Hizmetler & &
\end{tabular}

Tablo 3'de gösterildiği gibi Antalya destinasyonu için akıllı turizm destinasyonu uygulamaları kapsamında üç adet resmi uygulama olduğu ve ayrıca şikâyet ve öneriler için bir adet internet sayfasının bulunduğu tespit edilmiştir. Destinasyon içerikleri kapsamında çekicilik ve olanaklar boyutlarını kapsayan bir uygulama olmadığı belirlenmiştir.

Destinasyon bileşenlerinin ilki olan çekicilik unsuru ile ilgili Antalya Büyükşehir Belediyesi tarafından resmi olarak turistlere ve yerel halka 360 derece sanal gezinti gibi dijital rekreasyon deneyimlemesi sağlanmamasına rağmen, Kültür ve Turizm Bakanlığı internet sayfasından sadece Antalya müzesinin 360 derece sanal gezintisi 
yapılmaktadır. Bundan dolayı Antalya destinasyonunun akıllı turizm destinasyonu olma yolunda sanal gezinti ile dijital deneyimler için uygulamalar geliştirmesi önerilmektedir. Olanaklar unsuru ile ilgili de herhangi bir akıllı uygulamanın olmadığı görülmektedir. Bu kapsamda da Antalya destinasyonun hem turistlere hem de yerel halka çevre ile ilgili bilgiler sunan akıllı çevre uygulamaları geliştirmesi gerekmektedir.

Akıllı turizm destinasyonu kapsamında resmi olarak uygulamada olan Antalyakart, ICF Airport Mobile ve myAntalya uygulamaların hizmet vermektedir. Bu uygulamalar akıllı turizm destinasyonu kapsamında erişilebilirlik, mevcut paketler, etkinlikler ve yan hizmetler destinasyon bileşenlerini karşılamaktadır.

Antalyakart akıllı telefon uygulaması Şubat 2016'da hizmet vermeye başlamıştır. Toplu ulaşım araçlarında kullanılan Antalyakart biniş kartın bakiyesini sorgulamak, yükleme yapmak ve durağa yaklaşan otobüsleri görmek için Antalyakart uygulaması kullanılmaktadır. Kullanıcılar uygulama üzerinden kredi kartı ile otomatik dolum emri verilerek bakiyesi bittikçe kartlarının otomatik olarak dolumunu 3D güvenlik ile sağlayabilmektedir. Ayrıca kullanıcılar durağa yaklaşan otobüsleri, yakındaki bayileri görebilmekte ve otobüslerin hareket saatlerine uygulama üzerinden ulaşabilmektedir. Uygulamada bulunan "nasıl gidebilirim?" butonu hem turistlere hem de yerel halka gitmek istedikleri yerlerden geçen otobüsleri göstermektedir. Turistler tarafından uygulamanın rahatlıkça kullanılması için uygulamanın tüm özellikleri İngilizce olarak sağlanmaktadır. Uygulamada bulunan "nasıl gidebilirim?" butonu kullanılınca Antalya destinasyonunun haritasının açılması ve haritanın üzerinde Antalya destinasyonunda faaliyet gösteren turistik alanların, yeme-içme mekânlarının ve park alanlarının belirtilmesi özellikle turistlere seçenekler sunmaktadır. Ancak uygulamanın sesli destek özelliğinin bulunmaması bir eksiklik olarak görülebilir. Uygulamaya hem Türkçe hem de İngilizce sesli olarak otobüs hatları arama ve sesli olarak cevap alma özelliğinin eklenmesi hareketi kısıtlı bireylere kolaylık sağlayabilir. Antalyakart uygulaması tarafımızca telefon uygulaması olarak indirilip gözlemlenmiştir. Antalya destinasyonunda özellikle turistlerin rota olarak kullandığı rotalar üzerindeki otobüs hatları için Antalyakart uygulaması deneyimlenmiştir. Otobüslerin uygulamada gösterildiği zamanlarda duraklara geldiği ve uygulama üzerinde belirtilen rotalardan geçtiği belirlenmiştir.

ICF Airports Mobile uygulaması ise Haziran 2012 yılında hizmete sunulmuştur. Bu uygulama ile 24 saat uçak bilgilerine, gümrüksüz satış mağazaları, yiyecek içecek mekânlarına, otopark bilgisine, CIP hizmetlerine, terminal haritalarına ve araç park hesaplamasına erişilmektedir. Uygulama hem yerel halka hem de turistlere hizmet sunmak amacıyla Türkçe, İngilizce, Almanca ve Rusça dil seçeneklerine sahiptir. Uçuşlar ile ilgili olarak yurtiçi geliş-gidiş, yurtdışı geliş-gidiş uçakların kalkış ve iniş saatlerine erişim sağlanmaktadır. Gümrüksüz satış mağazaları kapsamında ise indirimler ve mağazaya gelmeden önce alışveriş için sipariş verme özelliği bulunmaktadır. Uygulamada ayrıca Antalya destinasyonu ile ilgili kısa tanıtım da bulunmaktadır.

Akıllı turizm destinasyonu bağlamında Antalya destinasyonun sahip olduğu en kapsamlı uygulama Nisan 2013'de hizmet vermeye başlayan myAntalya uygulamasıdır. Bu uygulama turistlere hitap etmek için İngilizce, Almanca ve Rusça dil seçeneklerine sahiptir. Uygulama üzerinden Antalya ile ilgili haberlere, duyurulara, hava durumuna, döviz kurlarına ve görülmesi gereken yerler ile ilgili bilgilere ulaşılabilmektedir. myAntalya uygulamasında yerel halka ve turistlere yönelik sunulan bilgiler Tablo 4'te özetlenmiştir. 
Tablo 4: myAntalya Uygulaması Sunulan Hizmetler

\begin{tabular}{|c|c|}
\hline Sunulan Hizmet & Alt Başlıklar \\
\hline Konaklama & $\begin{array}{l}\text { Apart Otel, Butik Otel, Kamp Alanı, Kayak Merkezi, } 5 \text { Yıldızlı Otel, } 4 \\
\text { Yıldızlı Otel, } 3 \text { Yıldızlı Otel, } 2 \text { Yıldızlı Otel, Özel Belgeli Otel, Pansiyon, } \\
\text { Tatil Köyü }\end{array}$ \\
\hline Turistik & Turistik Bilgi Merkezleri, Turistik Yerler \\
\hline Yeme-içme & $\begin{array}{l}\text { Bar-Pub, Dünya Mutfağı Restoranları, Türk Restoranları, Ev Yemekleri } \\
\text { Restoranları, Fast-Food, Simitçiler, Pide Restoranları, Kafeler, } \\
\text { Pastaneler, Starbucks }\end{array}$ \\
\hline Kültür-Sanat & Müzeler, Sanat Galerileri, Kültür Ve Sanat Merkezleri \\
\hline Ulaşım & $\begin{array}{l}\text { Otoyol Dinlenme Alanları, Banliyö, Deniz Ulaşımı, Havalimanı, Marina, } \\
\text { Oto Kiralama, Otobüs Terminali, Taksi, Teleferik, Tramway }\end{array}$ \\
\hline Eğlence & Bowling, Eğlence Parkları, Plaj, Sinema, Tiyatro Oyun Kafe \\
\hline Sosyal & Park-Koru Alanları, Sosyal Tesisler \\
\hline Spor & $\begin{array}{l}\text { Binicilik, Buz Pateni, Golf Sahaları, Spor Merkezleri, Spor Sahaları, } \\
\text { Stadyumlar }\end{array}$ \\
\hline Sağlık & Hastaneler, Eczaneler \\
\hline Finans & ATM, Banka Şubeleri, Döviz Büroları \\
\hline Alışveriş & $\begin{array}{l}\text { Alışveriş Merkezleri, Süpermarketler, Kitapçılar, Spor Malzemeleri, } \\
\text { Kırtasiye, Tekel Bayi }\end{array}$ \\
\hline Emniyet & Jandarma, Polis, Trafik, İtfaiye, Zabıta \\
\hline Eğitim & İlkokul, Yükseköğretim, Öğrenci Yurtları, Kütüphaneler \\
\hline İş-Ticaret & Fuar-Kongre Merkezleri, İş Merkezleri, Sanayi Merkezleri, Şarapçılık \\
\hline Kamu-Devlet & $\begin{array}{l}\text { Adliye, Belediye, Evlendirme Dairesi, Kaymakamlık, Konsolosluklar, } \\
\text { Muhtarlıklar, Noter, Postane, Tapu Dairesi, Türk Telekom, Valilik, } \\
\text { Elektrik-Doğalgaz, Milli Eğitim Müdürlüğü, SGK Müdürlüğü, Vergi } \\
\text { Dairesi }\end{array}$ \\
\hline Kargo-Lojistik & $\begin{array}{l}\text { Kurye, UPS, TNT, PTT, MNG Kargo, Yurtiçi Kargo, Fedex, DHL, Aras } \\
\text { Kargo }\end{array}$ \\
\hline Yerleşim & Mahalleler, Semtler, Siteler, Kooperatifler, Lojmanlar \\
\hline Dini & İbadethaneler \\
\hline Otopark & Açık Otoparklar, Kapalı Otoparklar \\
\hline Yakıt İstasyonu & $\begin{array}{l}\text { BP, Opet, Petrol Ofisi, Shell, Total, Türk Petrol, Akpet, Alpet, Bpet, } \\
\text { Starpet, Sunpet }\end{array}$ \\
\hline
\end{tabular}

Tablo 4'te özetlendiği gibi myAntalya uygulaması akıllı turizm destinasyonu bağlamında oldukça geniş bilgiyi hem yerel halka hem de turistlere sunmaktadır. Toplam 20 kategoride faaliyet gösteren kar amacı güden ve kar amacı gütmeyen örgütlerin iletişim adreslerine, facebook, twitter gibi sosyal medya profillerine ve bulundukları konuma bu uygulama aracılığıyla ulaşılabilmektedir. Uygulama kullanıcısının konumuna göre en yakın örgütten başlayarak önerilerde bulunmaktadır. $\mathrm{Bu}$ uygulamanın en önemli özelliklerinden biri de uygulama üzerinden şikâyet/öneri gönderebilme ve cevap alma özelliğidir. Ayrıca akıllı şehir kapsamında Antalya Büyükşehir Belediyesi'nin internet sayfasın üzerinden dilek, şikâyet ve öneriler kısmından hem vatandaşlar hem de turistler mail ile ulaşabilmekte ve cevap alabilmektedir.

\section{Sonuç ve Öneriler}

Son yıllardaki teknolojik gelişmeler mobil cihazların (pek çok ilişkili uygulamasıyla birlikte) ve sosyal ağların (Facebook, Twitter, Oturaklı, Google + ...) artan kullanımıyla sonuçlanmıştır. Mobil cihazların ve sosyal ağların gittikçe artan oranda kullanılması turizm sektörüne büyük bir etki yaparak en fazla değişimi yaşayan sektörlerden birisi olmasına neden olmuştur. Turistlerin seyahatlerine yönelik beklenti ve çıkarları 
doğrultusunda yolculuklarını planlama, bilgi arama ve karşılaştırma biçimleri, nasıl seçip rezervasyon yaptıkları, nasıl ziyaret ettikleri ve deneyimlerini nası paylaştıkları konusuna kadar tüketim alışkanlıklarında bir dizi değişikliğin yaşandığını söyleyebiliriz. Bunun sonucunda turizm endüstrisi her zamankinden daha ayrıntılı, esnek ve kişiselleştirilmiş ürünler, hizmetler ve deneyimler sunmaya başlamıştır. Bu nedenle kentlerin akıllı turizm uygulanmaları giderek ön plana çıkmıştır. Akıllı teknolojiler ile turizmi birleştiren akıllı turizm destinasyonları gelecekte sektörün önemli rekabet gücü haline gelecektir. Akıllı turizm destinasyonu olma yolunda ilerleyen ve uyumlu olan destinasyonlar avantajlı konuma geleceklerdir. Akıllı turizm destinasyonları turistlerin seyahat deneyimlerini arttırmaktadır. Çoğu zaman turistler ziyaret ettikleri yerler hakkında çok az bilgiye sahip iken akıllı turizm destinasyonları turistlerin ihtiyacı olan tüm bilgileri onlara sunarken turist talepleri ve şikâyetlerini de zamanında değerlendirebilir böylelikle destinasyona değerli bir bakış açısı yaratabilir. Bu nedenle destinasyondan sağlanan faydanın arttırılması için hem makro hem de mikro düzeyde akıllı turizm uygulamalarına entegre olması gerekmektedir. Bu nedenle bu çalışmada Türkiye'nin önemli turizm destinasyonu olan Antalya'nın akıllı turizm destinasyonu uygulamalarını incelenerek tespit edilen bulgular ışığında, konuyla ilgilenen araştırmacılara ve sektöre akılı turizm uygulamalarının geliştirilmesi için öneriler sunulmasıdır amaçlanmıştır. Bu çalışmada öncelikle literatürde yeni bir kavram olan akıllı turizm destinasyonu ile ilgili kuramsal çerçeve incelendikten sonra Antalya'nın akıllı turizm uygulamaları incelenmiştir. Çalışma akıllı turizm destinasyonu literatürüne ışık tutmasına rağmen konun yeni olması nedeni ile sınırlılıkları vardır.

Türkiye'nin önemli turizm destinasyonlarından birisi olan Antalya'nın akıllı turizm destinasyonu olma yolundaki çalışmaları incelendiğinde uygulamaların yeni başladığı ve Antalya'nın yolun çok başında olduğu söylenebilir. Literatürde de belirtildiği gibi akıllı turizm destinasyonu olma yolunda işletmeler, turistler, yerel halk, yerel yönetimler ve hükümet işbirliği gerekmektedir.

Çalışmanın amacı doğrultusunda Antalya destinasyonunun Türkiye'nin akıllı bir turizm destinasyonu olması ve turistler tarafından Antalya destinasyonunun akıllı turizm destinasyonu olarak tanınması için faydalı olabilecek stratejiler aşağıda belirtilmiştir.

Öncelikle Antalya Büyükşehir Belediyesi, Antalya Destinasyon Yönetim Örgütü ve üniversite işbirliği ile özel bir çalışma grubu kurulmalıdır. Bu çalışma grubu Antalya'nın akıllı turizm destinasyonu olması için fizibilite çalışmaları yapmalı ve bu çalışmalar akıllı destinasyon alma yolundaki hedef ve stratejileri belirlemelidir. Bu süreçte paydaşlara akıllı turizm destinasyonu olmanın önemine yönelik farkındalık kampanyaları ve eğitimler düzenlenebilir.

Akıllı turizm destinasyonu projesi Antalya'nın uluslararası bir turizm merkezi olma konumunu iyileştirmeyi amaçlamalıdır. Bunun gerçekleşmesi için, yeniliği teşvik eden, erişilebilirliği ve sürdürülebilirliği geliştiren bilgi iletişim teknolojilerini yaymak ve geliştirmek, belirgin ve son derece rekabetçi hizmetlerin yaratılabileceği yeni mekanizmalar aramak gerekmektedir. Destinasyonda teknolojinin yoğun kullanımı yoluyla bilgi depolanması, analiz edilmesi ve yönetilmesi gereken bir veri hacmi oluşturulmalıdır. Bu amaca ulaşmak için bilgi edinme ve yönetme kabiliyeti olan büyük veri platformları (makro veriler) kullanılmaktadır. Bu teknoloji üretilen bilgilerin yönetimi, kullanımı ve analizi için verimli çözüm sunmaktadır. Güncelleme sıklığının yüksek olduğu, farklı veri türleri ve çoklu besleme kanalları, verilerin işleme hızı, bilgi yakalama, analiz araçları, gerçek zamanlı olarak veri korelasyonu, sunumu ve bilgilerin analizi yapılan büyük veri platformları (makro veriler) destinasyonlar için rekabet 
avantajı sağlayacaktır. Akıllı destinasyon tarafından işletilen teknolojilerin ürettiği büyük ölçekli veri platformları, yönetim sistemleri ve turizm istihbaratı için çok sayıda fırsat sunmaktadır. Örneğin bu verilerin incelenmesi sayesinde sektördeki şirketler için büyük iş fırsatları üretebilir ve yeni teknoloji başlatma fırsatları yaratabilir. Ziyaretçilerin ilgi çeken yerleri tam olarak belirlemelerine yardımcı olan temel bilgiler sunan yer belirleme sistemleri; ziyaretçinin kültürel deneyimini zenginleştiren video haritalama ve holografi teknikleri, vb. uygulamalarda büyük veri platformları tarafından yönetilmektedir. Bu noktada Antalya için destinasyondaki tüm paydaşların aktif katıımı ile büyük veri platformu (makro veriler) kurulması önceliklendirilmelidir. Bu platform üzerinden turistler bilet satın alma, rezervasyon yapma, sosyal iletişim gibi taleplerini karşılarken işletmeler de turistlerin intiyaçlarına yönelik reklam, satış ve tanıtım yapabilmelidir. Hükümet ve yerel yönetimler ise bir paydaş olarak bilgi merkezindeki veri arşivlerini kullanarak yapacağı analizler sonucuna göre Antalya'nın geleceğe yönelik turistik politikalarını düzenleyebilecektir. Bu platform aracılığı ile yapılan online bilet satışları turistlerin zaman kaybını önlerken, işletmelerin maliyetlerini azaltması, servis kalitesini arttırması ve kontrollerini kolaylaştırmasını sağlayacaktır.

Seyahat öncesi destinasyon, ürünler ve hizmetler hakkında oluşturulmuş bir bilgi kümesine (metin, resim, ses, video, enformasyon, haritalar ...) erişim, turistler için seçme deneyimini belirgin bir şekilde zenginleştirir. Seyahat esnasında destinasyondaki mobil teknolojinin ve uygulamalarının kullanımındaki artış, tüm turist deneyimini daha kolay ve daha esnek hale getirir. Turist, sürekli olarak ürün ve hizmet sağlayıcıların yanı sıra bağlı diğer turistlerle etkileşime girer ve yerinde daha akıllı kararlar verebilir. Seyahat sonrası işletmeler ve destinasyonlar için ana zorluk, nerede ve kimin ürün ve hizmetleri hakkında konuştuğunun bilinmesidir. Özellikle sosyal ağlar üzerinde, turistler arasındaki memnuniyet seviyesini kontrol altına alıp sürekli iyileştirme sistemlerini yerleştirmeyi ve yeni sadakat planları geliştirmeyi mümkün kılan bir dizi farklı etkileşimli iletişim uygulaması bulunmaktadır. Büyük veri platformu aracılığıyla tüm bunların sağlanması da mümkün olacaktır.

Büyük veri platformu tarafından Antalya destinasyonuna özgü bir mobil uygulama (özellikle de akıllı telefonlar ve tabletlere yönelik) hazırlanmalıdır. Bu uygulama ziyaretçilere destinasyon hakkında bilgi arama, ürünler ve servisler, coğrafi konum bilgilendirmesi, özel teklifler hakkında gerçek zamanlı bilgi, sanal gerçeklik gibi bilgiler sağlamalıdır.

Bir diğer önceliklendirilmesi gereken husus ise; Antalya'da destinasyona özgü akıllı turizm ofisi oluşturulmasıdır. Bu ofis güçlü bir teknolojik temele dayanırken aynı zamanda destinasyonu pazarlama yeteneğine de sahip olmalıdır. En gelişmiş teknolojileri ve uygulamaları kullanarak bölge ve ziyaretçi arasında bir buluşma noktası olarak kurulamalıdır. Bu ofis yalnızca bilgi vermeyi ve destinasyonu teşvik etmeyi değil, aynı zamanda pazarlama sürecine yardımcı olarak bölgedeki turistik ürünlerin ziyaretçi tercihlerine göre bölümlere ayrılmasını sağlamalıdır. Teknolojik, çok kültürlü ve çok dilli bileşenlere sahip olması gereken bu akıllı turizm ofisi, ziyaretçinin destinasyonla etkileşime girmesine imkan veren, turistleri destinasyona çekerken, aynı zamanda turistlerin destinasyon hakkındaki birçok bilgiyi toplamasına ve analiz etmesini sağlamalıdır. Ofis destinasyondaki uygulamaları etkinleştirmek ya da indirmeye teşvik edebilen, rezervasyon ve satış hizmetleri sunabilen ve gerektiğinde ziyaretçilere destinasyona bağlı mobil uygulamaların kullanımı konusunda bilgi verebilen bir yapıya sahip olmalıdır. Bu akılı ofis büyük veri platformları (makro veriler) ile entegre çalışabilir. Ya da ofis Antalya destinasyon yönetim örgütü tarafından yönetilmelidir. Ayrıca Antalya'daki mevcut destinasyon yönetim örgütünün sosyal medyayı daha aktif bir şekilde kullanması da avantaj sağlayacaktır. Son dönemlerde 
popüler olan sosyal medya veya web sayfaları üzerinden turist yorumlarına daha hızlı dönüş sağlayarak turistlerin online şikayetlerini daha hızlı ve memnun edici şekilde yönetebilecektir. Turistlerin, bilgilenmek ve destinasyonla etkileşim kurmak için sosyal medyayı önemli bir şekilde kullanmaları göz önüne alındığında, online promosyon stratejisi içerisinde özel bir sosyal medya iletişim stratejisi oluşturulmalıdır.

Önemli turistik destinasyonların sunduğu akıllı turist kartları Antalya destinasyonu için oluşturulmalıdır. Diğer akıllı destinasyonlarda çeşitli isimlerle turistlerin kullanımına sunulan bu kart için Antalya'nın akıllı destinasyon kimliği oluşturulması ile uyumlu bir isim kullanılması (SmartExplore Antalya, Smart Antalya, Smart Card, SmArTourist Card, Turquoise Card) turistler açısından da dikkat çekici olacaktır. Bu kart ziyaretçilerin destinasyonun sunduğu çeşitlilikler (ulaşım, rehberler ve geziler, müzeler ziyaretleri, performanslar vb.) hakkında daha fazla bilgi edinmesini standartlaştırır ve kolaylaştırır. Bu akıllı kartın Antalya destinasyonu için oluşturulması Antalya'nın akıllı turizm destinasyonu olma yolunda atacağı önemli bir adım olarak düşünülebilir. Oluşturulacak bu kartı turistler havalimanı, önemli turistik yerler, oteller aracılığı ile veya internet üzerinden de satın alınabilmelidir. Kart aynı zamanda QR kod ve mobil uygulama şeklinde de erişilebilir olmalıdır. Turistleri gerçek zamanlı olarak doğru yerlere yönlendiren akıllı bir seyahat rehberi niteliğindeki bu akıllı turist kartı, turist deneyimini çok daha kolay hale getirmek için şehir hizmetlerini bir araya getirmelidir. Şehirdeki turistik çekicilikler, restoranlar, rekreasyon alanları veya alışveriş merkezi promosyonları ve indirimleri, hava tahmini, trafik akışı ve insan güvenliği hakkında gerçek zamanlı veriler sağlamalıdır. Kartın kullanımı ile turistlerin şehir merkezi ve diğer turistik cazibe merkezlerinde daha fazla zaman geçirmesi sağlanarak destinasyona ve yerel halkada ekonomik katkı sağlayacağı düşünmektedir.

Ücretsiz Wi-Fi turistin ve yerel sakinlerin en çok talep ettiği hizmetler arasındadır. Ücretsiz Wi-Fi çözümlerinin online pazarlama konusunda sağladığı faydalar açısından değerlendirildiğinde Wi-Fi çözümleri hem arz hem de talep için caziptir. Antalya'da bazı turistik noktalarda ve plajlarda sağlanan ücretsiz Wi-Fi şehrin diğer cazibe merkezlerinde de makul bir bant genişliği sağlamalıdırlar.

İki boyutlu barkod olan QR kodlarının kullanımı artırılmalıdır. Turizm sektöründe de kullanımı hızlanan bu kodlar turistler ve destinasyon arasında hızlı ve basit etkileşime izin vermektedir. Bilgi panoları, promosyon malzemeleri, faturalama süreçlerini kolaylaştırmak ve sadakat kampanyalarını zenginleştirmek için QR kodları kullanılabilir. Yine destinasyondaki tarihi ve doğal çekicilikler belirli noktalarındaki bu QR kodlar aracılığı ile çok dilli şekilde tanıtılabilir. Antalya'nın önemli turistik noktalarda turizm ofislerinde görsel-işitsel ekipmanlar (dokunmatik ekranlar) aracılığıyla turistlere Antalya'nın kültürü ve tarihi hakkında ayrıntılı bilgi sağlanabilir. Turistlere Antalya'nın turistik çekiciliklerini dijital rekreasyonunu deneyimlemesi için belirli noktalarda (havalimanı, otogar vb.) istasyonlar kurulabilir.

Kaynakların ve hizmetlerin kalitesini ve verimliliğini artırmak için sürdürülebilir bir büyüme modeli sağlamayı amaçlayan projeler oluşturulup, tüm paydaşların projelere katılımı sağlanabilir. Antalya'nın akılı turizm destinasyonu olması için projelere aktif katılım gösteren turizm paydaşlarına tanıtım ve benzeri konularda öncelik ve ödül uygulamaları oluşturulabilir. Böylelikle projelere katıım arttırılabilir. Yine konu ile ilgili yerel halkın farkındalığı arttırılmalı ve konu ile ilgili eğitimler verilmelidir. Tüm bu uygulamalar planlanırken Antalya'nın yeşil dengesi gözetilmelidir.

Tüm bunlara ek olarak kent içindeki ziyaretçi hareketliliğini belirlemek için, özel kameralar kullanarak insanları ve araçları saymak için stratejik noktalarda sensörler 
yerleştirilebilir. Plajların ve havanın durumunu gösteren panoramik bir turistik web kamerası, video haritalama vb. uygulamalar kullanılabilir. Gerçek zamanlı trafik yönetim sistemleri, otopark yönetimi için mobil uygulamalar hayata geçirilebilir.

Akıllı turizm destinasyonu konusunun literatürde yeni olması ve Türkiye'de akıllı turizm destinasyonu uygulamalarının az olması, Antalya'nın konu ile ilgili adımlarının henüz çok yeni olması çalışmanın kısıtları arasındadır. Çalışmanın katkılarını genişletmek için yeni araştırmalara intiyaç vardır. Sonraki çalışmalar farklı akıllı turizm destinasyon uygulamaları ile karşılaştırmalı analizler yapılabilir. Yine sonraki çalışmalarda destinasyondaki tüm paydaşların görüşleri alınabilir ve Antalya destinasyonuna gelen turistlerin akıllı destinasyondan beklentileri ölçülebilir. Turizm sektörü ve yerel yönetimler de ortak bir çalışma ile dünyadaki akıllı turizm destinasyonu uygulamalarını Antalya destinasyonuna uyarlanabilirliği üzerinde çalışabilir.

\section{Kaynakça}

Altunışık, R., Coşkun, R., Bayraktaroğlu, S. ve Yıldırım, E. (2010), Sosyal Bilimlerde Araştırma Yöntemleri SPSS Uygulamalı, 6. Baskı, Sakarya: Sakarya Yayıncılık.

Antalya Büyükşehir Belediyesi (2015), 'Antalya Akıllı Kent Oluyor', http://www.antalya.bel.tr/haberler/antalya-akilli-kent-oluyor (15.01.2017).

Antalya Büyükşehir Belediyesi (2016), 'Uluslararası Akıllı Şehirler Konferansı', http://www.antalya.bel.tr/calismalarimiz/yonetim-ve-e-belediyecalismalari/uluslararasi-akilli-sehirler-konferansi (15.01.2017).

Avrupa Komisyonu (2015), 'Smart Cities', https://ec.europa.eu/digital-singlemarket/en/smart-cities (10.04.2016).

Benckendorff, P., Sheldon, P. ve Fesenmaier, D. R. (2014), Tourism Information Technology, Oxford: CAB International.

Berst, J. (2013), Smart Cities Readiness Guide, The planning Manual for Building Tomorrow's Cities Today, Smart Cities Council, Seattle, USA. http://www.corviale.com/wp-content/uploads/2013/12/guida-per-le-smart-city.pdf (25/12/2016).

Buhalis, D. ve Amaranggana, A. (2013), Smart Tourism Destinations. Z. Xiang and I. Tussyadiah (eds.), Information and Communication Technologies in Tourism 2014, ss. 553-564, Springer International Publishing, Switzerland.

Buhalis, D. ve Amaranggana, A. (2015), Smart Tourism Destinations: Enhancing Tourism Experience Through Personalisation of Services, In I. Tussyadiah \& A. Inversini (Eds.), Information and Communication Technologies in Tourism 2015, ss. 377-389, Heidelberg: Springer.

Caragliu, A., Bo, C.F., ve Nijkamp, P. (2009), Smart Cities in Europe. Serie Research Memoranda 0048, VU University Amsterdam, Faculty of Economics, Business Administration and Econometrics.

Chourabi, H., Nam, T., Walker, S., Gil-Gracia, R.J., Mellouli, S., Nahon, K., Prado, T.A. ve Scholl, H.J. (2012), Understanding Smart Cities: An Integrative Framework, 45th Hawaii International Conference on System Sciences, 04 Jan - 07 Jan 2012, Maui, USA, 2289-2997.

Chui, M., Löffler, M., ve Roberts, R. (2010), "The Internet of Things", McKinsey Quarterly, 2, 1-9.

Cohen, B. (2012), 'The Smart City Wheel', http://www.smart-circle.org/smart-city/boydcohen-smart-city-wheel/ (26/12/2016).

Creswell, J. W. (2007), Qualitative Inquiry \& Research Design - Choosing Among Five Approaches, 2nd ed., SAGE Publications: Thousand Oaks, California 
Dirks, S. ve Keeling, M. (2008), A Vision of Smarter Cities, How Cities Can Lead the Way into a Prosperous and Sustainable Future, IBM Global Services Publication, USA.

Egger, R. (2013), "The Impact of Near Field Communication on Tourism", Journal of Hospitality and Tourism Technology, 4(2), 119-133.

Etro, F. (2009), "The Economic Impact of Cloud Computing on Business Creation, Employment and Output in Europe", Review Business and Economics, 54(2), 179-208.

Giffinger, R., Fertner, C., Kramar, H., Kalasek, R., Pichler-Milanovic, N., ve Meijers, E. (2007), Smart Cities: Ranking of European Medium-Sized Cities, Centre of Regional Science, Vienna University of Technology.

Gretzel, U., Sigala, M., Xiang, Z. ve Koo, C. (2015), "Smart Tourism: Foundations and Developments", Electron Markets, 25, 179-188.

Harrison, C., Eckman, B., Hamilton, R., Hartswick, P., Kalagnanam, J., Paraszczak, J. ve Williams, P. (2010), "Foundations for Smarter Cities", IBM Journal of Research and Development, 54(4), 1-16.

Hint Hükümeti (2015), Smart City Guidelines, Government of India Ministry of Urban Development, India.

Hwang, J., Park, H. Y. ve Hunter, W.C. (2015), "Constructivism in Smart Tourism Research: Seoul Destination Image", Asia Pacific Journal of Information Systems, 25(1), 163-178.

ISO (2014), 'How to Measure the Performance of Smart Cities', https://www.iso.org/news/2015/10/Ref2001.html (10.04.2016).

Kamu Teknoloji Platformu (2016), 'Akıllı Kentler Masabaşı Araştırması', http://www.akillisehirler.org/wp-content/uploads/2016/08/Xsights-

Ak\%C4\%B1Il\%C4\%B1-Kentler-Masa-Ba\%C5\%9F\%C4\%B1-

\%C3\%87al\%C4\%B1\%C5\%9Fmas\%C4\%B1.pdf (10.04.2016).

Kim, H.M. ve Han, S.S. (2012), "City Profile: Seoul", Cites, 29(2), 142-154.

Koo, C., Gretzel, U., Hunter, W. C. ve Chung, N. (2015), "The Role of IT in Tourism", Asia Pacific Journal of Information Systems, 25(1), 99-104.

Lopez de Avila, A. (2015), Smart Destinations: XXI Century Tourism. ENTER2015 Conference on Information and Communication Technologies in Tourism, Lugano, Switzerland, February 4-6.

Meijer, A. ve Bolivar, M.P.R. (2013), Governing the Smart Sustainable City: Scaling-Up the Search for Socio-Techno Synergy, EGPA, Edinburgh.

Mingjun, W., Zhen, Y., Wei, Z., Xishang, D., Xiaofei, Y., Chenggang, S., Xuhong, L., Fang, W. ve Jinghai, H. (2012), A research on experimental system for Internet of things major and application project. 3rd International Conference on System Science, Engineering Design and Manufacturing Informatization (ICSEM), 20-21 Oct. 2012, Chengdu, China, ss. 261-263.

Morabito, V. (2015), Big Data and Analytics, Berlin: Springer International Publishing.

Nam, T. ve Pardo, T.A. (2011), Conceptualizing Smart City with Dimensions of Technology, People, and Institutions, The Proceedings of the 12th Annual International Conference on Digital Government Research, 282-291.

Nenonen, S. ve Storbacka, K. (2010), "Business Model Design: Conceptualizing Networked Value Co-creation", International Journal of Quality and Service Sciences, 2(1), 43-59.

Rios, P. (2008), "Creating "The Smart City". Thesis, University of Detroit Mercy, USA.

Schaffers, H,, Komninos, N., Tsarchopoulos, P., Pallot, M., Trousse, B., Posio, E., Fernadez, F., Hielkema, H., Hongisto, P. ve Almiral, E. (2012), Landscape and Roadmap of Future Internet and Smart Cities, Technical Report, 222, https://hal.inria.fr/hal-00769715/document 
Sigala, M. (2015), "From Demand Elasticity to Market Plasticity: A Market Approach for Developing Revenue Management Strategies in Tourism", Journal of Travel and Tourism Marketing, 32(7), 812-834.

Türkiye Bilişim Vakfı (2016), 'Akıllı Şehir Yol Haritası', http://www.tbv.org.tr/akilli-sehiryol-haritasi,DP-1117.html (10.04.2016).

Türkiye Bilişim Vakfı (2016), 'Akıllı Şehirler Değerlendirme Raporu', http://tbv.org.tr/Turkiye_Akilli_Sehirler_Degerlendirme_Raporu-Web.pdf (10.04.2016).

UK Department of Business, Innovation and Skills (2013). Smart Cities: Background Paper. IBS/13/1209, London, UK.

Vicini, S., Bellini, S. ve Sanna, A. (2012), How to Co-create Internet of Things-Enabled Services for Smarter Cities, The First International Conference on Smart Systems, Devices and Technologies, 55-61.

Wang, D. ve Xiang, Z. (2012), The New Landscape of Travel: A Comprehensive Analysis of Smartphone Apps. In M. Fuchs, F. Ricci ve L. Cantoni (Eds.), Information and Communication Technologies in Tourism 2012 (ss. 308-319). Wien: Springer.

Wang, D., Park, S. ve Fesenmaier, D. (2012), "The Role of Smartphones in Mediating the Tourism Experience", Journal of Travel Research, 51(4), 371-387.

Washburn, D., Sindhu, U., Balaouras, S., Dines, R.A., Hayes, N.M., ve Nelson, L.E. (2010), Helping ClOs Understand "Smart City" Initiatives: Defining the Smart City, Its Drivers, and the Role of the CIO, Cambridge, MA: Forrester Research Inc.

Yıldırım, A. ve Şimşek, H. (2003), Sosyal Bilimlerde Nitel Araştırma Yöntemleri, Ankara: Seçkin Yayıncılık.

Yıldırım, A. ve Şimşek, H. (2008), Sosyal Bilimlerde Nitel Araştırma Yöntemleri (6. Baskı), Ankara: Seçkin Yayıncılık.

Yoo, K.H., Sigala, M. ve Gretzel, U. (2015), Exploring TripAdvisor, In R. Egger, I. Gula, \& D. Walcher (Eds.), Open Tourism - Open Innovation, Crowdsourcing and Collaborative Consumption challenging the tourism industry. (ss. 239-255). Heidelberg: Springer Verlag.

Zhang, L.Y., Li, N. ve Liu, M. (2012), "On the Basic Concept of Smart Tourism and Its Theoretical System", Tourism Tribune, 27(5), 66-73.

Zhang, Y. (2010), "Interpretation of Smart Planet and Smart City", China Information Times, 10, 38-41. 